\title{
Working
}

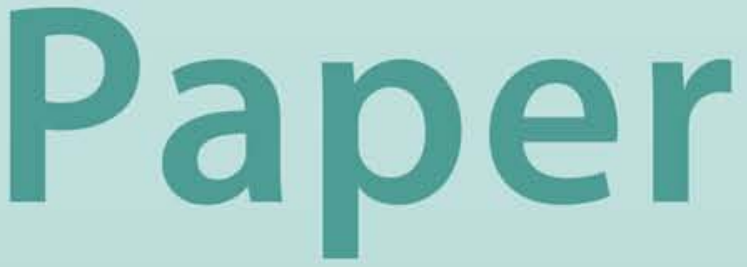


Commodity Price Volatility, Cyclical Fluctuations, and Convergence: What is Ahead for Inflation in Emerging Europe?

Edda Zoli 


\title{
IMF Working Paper
}

European Department

\section{Commodity Price Volatility, Cyclical Fluctuations, and Convergence: What is Ahead for Inflation in Emerging Europe?}

\author{
Prepared by Edda Zoli ${ }^{1}$
}

Authorized for distribution by Luc Everaert

March 2009

\begin{abstract}

\section{This Working Paper should not be reported as representing the views of the IMF.} The views expressed in this Working Paper are those of the author(s) and do not necessarily represent those of the IMF or IMF policy. Working Papers describe research in progress by the author(s) and are published to elicit comments and to further debate.
\end{abstract}

This paper assesses the role of international commodity prices, cyclical fluctuations, and convergence in driving inflation in 18 European emerging economies. Country specific VARs and panel estimates indicate that international commodity price shocks have a significant impact on domestic inflation, but the inflation response is asymmetric for positive and negative shocks. Cyclical fluctuations explain a relative small share of inflation variability, and the inflation response is asymmetric during upturns and downturns. Price convergence is estimated to add nearly 3 percentage points to headline inflation, for the average country whose price level is about 50 percent relative to the EU-15 average.

JEL Classification Numbers:C23, C32, E31

Keywords: Inflation, Commodity Prices, Price Convergence

Author’s E-Mail Address:EZoli@imf.org

\footnotetext{
${ }^{1}$ I would like to thank Alex Pivovarsky for his contributions in the initial stage of this project, Emil Stavrev and Luc Everaert for useful comments, and Pavel Lukyantsau for research assistance.
} 


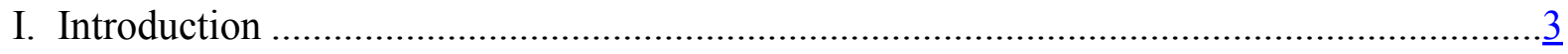

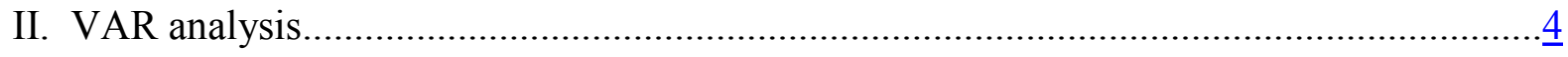

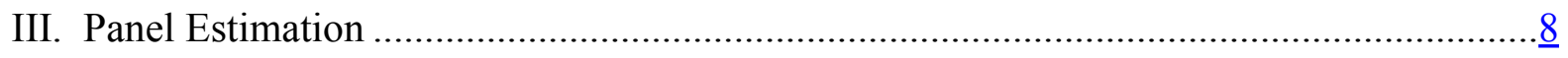

IV. Conclusion: What is Ahead for Inflation in Emerging Europe?...................................13

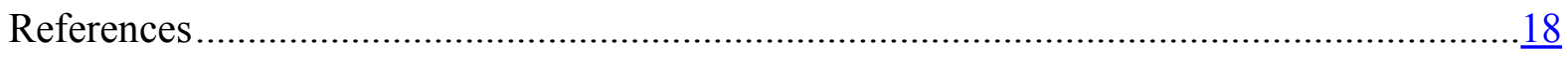

Tables

1. Response of Domestic Energy Inflation to International Oil Price Inflation Shocks ............ $\underline{5}$

2. Response of Domestic Food Inflation to International Food Price Inflation Shocks ............ $\underline{6}$

3. Response of Core Inflation to Shcokcs to Domestic Food and Energy Price Inflation ......... 1

4. Panel Regression Results ...............................................................................

Figures

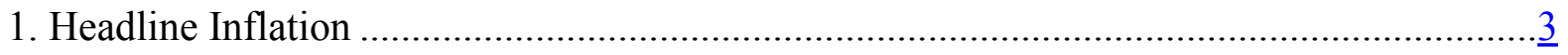

2. Variance Decomposition of Headline Inflation ....................................................... 5

Appendixes

1. Variable Definition and Data Sources .......................................................................... 14

2. Other Panel Results.......................................................................................... 


\section{INTRODUCTION}

High inflation has been one of the challenges facing European emerging economies since the start of the transition process. Even after the sharp disinflation of the 1990s, inflation rates remain significantly higher than in advanced economies. Moreover, inflation edged up in 2007, with some countries hitting double-digit inflation in 2008 (Figure 1).

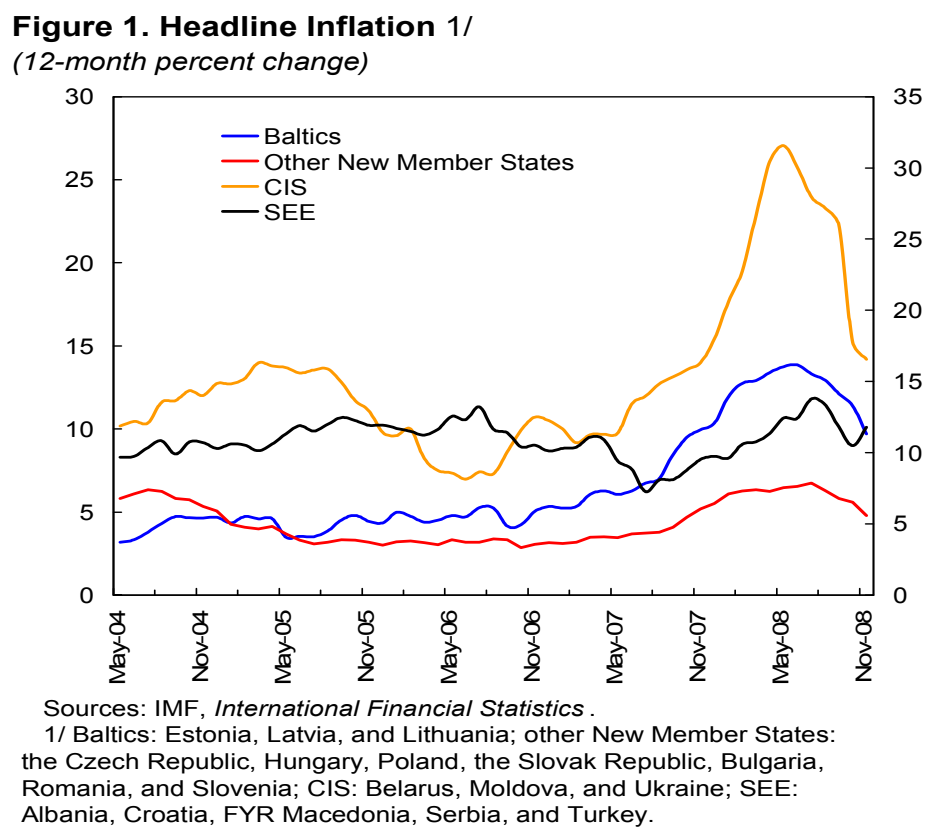

Several factors may be driving inflation in emerging Europe. Recent commodity price shocks have contributed to a surge in the first half of 2008. Due to the large share of food in the consumption basket, on average, food price inflation had led to an increase in headline inflation of almost 6 percentage points, during 2007Q2-2008Q2, while oil price inflation had added about 2 percentage points to headline inflation, on average, during the same period. At the same time, robust economic growth over the past years is likely to have intensified price pressure. In addition, other forces, including catching up and transition related factors - such as price deregulation, subsidy reduction, rising demand due to higher income, BalassaSamuelson effects - may be also key determinants of inflation in emerging Europe.

Against this background, what is the outlook for inflation in the near future, as food prices ease, oil prices reverse the sharp gains of the past year, and economic activity slows down in the wake of the international financial crisis? Also, as the convergence process proceeds, what are the implications for inflation in the medium-term? This paper tries to address these issues, by assessing the effect of commodity prices shocks, cyclical fluctuations, and transition related variables on headline inflation and its main components in emerging Europe. The paper also studies whether surging domestic energy and food prices have spilled over into core inflation. Concerns about second-round effects remain relevant even as commodity prices moderate, because domestic price pressures may persist for some time as a result of the continuing feed-through of past commodity price increases. 
While a vast literature has examined the determinants of inflation in emerging Europe, most studies have focused either on single countries or on the New Member States (NMS) of the European Union. ${ }^{2}$ Instead this papers covers 18 European emerging economies. The empirical analysis uses two methodologies. First we estimate a vector autoregressive (VAR) model, and examine the dynamic response of inflation to shocks in world fuel and food prices as well as domestic output growth. ${ }^{3}$ The VAR allows to control for endogenous movements in policy rates and exchange rates. The VAR also provides useful insights on how long it takes for the shocks to be transmitted into domestic prices and dissipate. As a second approach, we estimate a panel model, that allows to introduce additional control variables other than those included in the VAR, such as changes in consumption tax rates, and variables capturing price and income level convergence.

Results from the empirical analysis indicate that international commodity price movements have a significant impact on domestic inflation, but the inflation response is asymmetric for positive and negative shocks. Cyclical fluctuations, while contributing to inflation, explain a relative small share of inflation variability, and the inflation response is asymmetric during upturns and downturns. Price convergence is estimated to add nearly 3 percentage points to headline inflation, for the average country whose price level is about 50 percent relative to the EU-15 average.

The reminder of the paper is organized as follows. Section II presents the VAR analysis; section III discusses the panel estimates, and section IV concludes.

\section{VAR ANALYSIS}

Two different VAR models are estimated at monthly frequency for 16 European emerging economies over the period mid 1990s-early $2008 .{ }^{4}$ The first includes the following variables: ${ }^{5}$ world fuel and food price inflation, changes in the industrial production index, as a measure of economic activity, headline inflation, the 3-month money market rate, and changes in the nominal effective exchange rate. In the second model, headline inflation is replaced by its main three components - domestic energy inflation, domestic food inflation, and core inflation. $^{6}$

\footnotetext{
${ }^{2}$ Recent studies on inflation determinants for individual countries include, for example, Basu et al. (2007) on Russia, and Surti (2008) on Slovenia. Recent cross country studies on emerging Europe comprise Allard (2007), Égert (2007, 2008), Hammermann and Flanagan (2007), Mody and Ohnsorge (2007), Zhou (2007), Beirne and Staehr (2008), Choueiri, Ohnsorge, and van Elkan (2008), Dubravko and Klau (2008), Franta, Saxa and Smidkova (2008), Schnabl (2008), Stavrev (2008), Vanags and Suardi (2008).

${ }^{3}$ VAR models have been widely used in the literature to analyze the response of inflation to commodity price shocks. Several recent studies have focused particularly on oil shocks (see, for instance, Blanchard and Galí (2007) and IMF (2008a,b) on advanced economies). For studies on impact of food price shocks in Latin America and in European advanced economies see, IMF (2008a,b) respectively.

${ }^{4}$ The estimation period varies from country to country depending on data availability. The sample includes Bulgaria, Croatia, the Czech Republic, Estonia, Hungary, Latvia, Lithuania, Macedonia, Poland, Romania, Serbia, Slovak Republic, Slovenia, Turkey, and Ukraine.

${ }^{5}$ See Appendix I for variable definition and data sources.

${ }^{6}$ For NMS and Turkey core inflation is measured by the HICP overall index excluding energy, food, alcohol and tobacco. For the other countries a measure of core inflation - as much as possible consistent with the HICP
} 
Both models are "near" VAR, as international food and fuel prices depend only on their lagged values, and not on domestic variables. Tests of block-exogeneity confirm the validity of this assumption. The number of lags is determined through standard information criteria. Impulse responses are obtained using the Cholesky decomposition, with the variables ordered as listed above. In the energy equation for Ukraine a dummy is included among the explanatory variables to account for the spike in energy import price from Russia in 2006-07.

The results indicate that output growth movements are responsible on average for only 5.3 percent of inflation variability, with Poland, Romania and Turkey being the countries where growth explains a larger share of inflation variance (Figure 2). The analysis of impulse responses indicates that an increase in real growth by 1 percentage point would result in a surge in headline inflation of less than 0.5 percentage points in all sample countries, suggesting that shocks to output seem to have a limited impact on inflation variability in emerging Europe.

Changes in international commodity prices and domestic factors are significant drivers of inflation in emerging Europe. World commodity prices typically explain on average about 19 percent of the variation in headline inflation, with world fuel and food prices playing a similar role. There are, however, differences across countries. In Estonia, Lithuania, Poland, Serbia and Ukraine the contribution of world fuel prices movements to headline inflation volatility is greater than in other countries. In the Baltics and Ukraine the contribution of world food price to inflation volatility is particularly high. On average, inflation inertia explains about 50 percent of inflation volatility, and policy rates and exchange rates together about 18 percent.

Figure 2: Variance Decomposition of Headline Inflation (Percent)

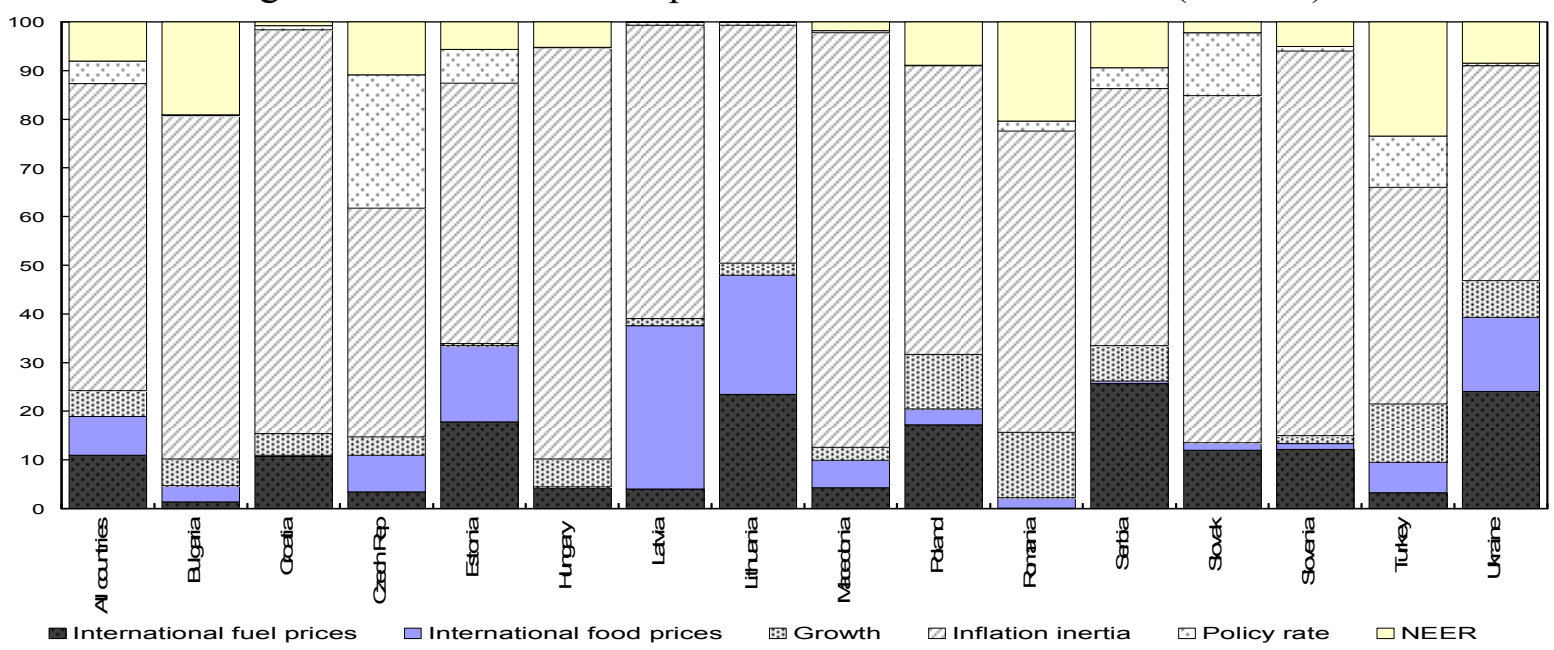

Sources: IMF, International Financial Statistics, national authorities, and author's estimates.

The disaggregation of consumer price inflation (CPI) into its main components provides further insights on the transmission of international commodity price shocks. Impulse

overall index excluding energy, food, alcohol and tobacco definition — was constructed using national authorities data. 
responses suggest that movements in world fuel prices have a significant impact on domestic energy inflation in most countries (Table 1). The size of the pass-through is similar across countries. The pass-through is very rapid - the peak effect is typically reached in six months (or less) after the shock-, but the impact of the shock generally dissipates within one year. This result is consistent with the findings in IMF (2008) on a larger group of emerging economies. This suggests that the decline in oil prices started in the second half of 2008 may impact inflation fully in mid-2009. The exchange rate regime does not seem to have a significant impact on the maximum inflation response to world oil price shocks.

Table 1: Response of Domestic Energy Inflation to International Oil Price Inflation Shocks (Percentage points) $1 / 2 /$

\begin{tabular}{lccc}
\hline & $\begin{array}{c}\text { Response after } \\
\text { 6 months }\end{array}$ & $\begin{array}{c}\text { Response after } \\
12 \text { months }\end{array}$ & $\begin{array}{c}\text { Peak response } \\
\text { within } 12 \\
\text { months }\end{array}$ \\
\hline Bulgaria & 0.8 & 0.0 & 1.2 \\
Croatia & 0.1 & 0.0 & 0.1 \\
Czech rep. & 1.0 & 0.0 & 1.0 \\
Estonia & 1.4 & 0.0 & 1.9 \\
Latvia & 1.0 & 0.0 & 1.0 \\
Lithuania & 1.2 & 1.2 & 1.2 \\
Macedonia & 1.5 & 1.3 & 1.6 \\
Poland & 0.6 & 0.5 & 0.6 \\
Serbia & 1.6 & 0.0 & 1.6 \\
Slovenia & 1.3 & 0.9 & 1.4 \\
Slovak Rep. & 1.8 & 0.0 & 1.8 \\
Turkey & 1.8 & 0.0 & 1.8 \\
Average & 1.2 & & \\
Inflation targeters & 1.2 & 0.3 & 1.3 \\
Pegged exchange rates & 1.1 & 0.1 & 1.3 \\
\hline
\end{tabular}

Sources: IMF, International Financial Statistics, national authorities, and author's estimates. $1 /$ Results are reported only for countries for which responses are significant at 95 percent (or higher) level.

2/ Size of the shock: 10 percentage point increase in world oil price inflation.

Shocks to international food price inflation also have a significant impact on domestic food inflation in many emerging economies (Table 2). A hike in world food inflation by 10 percentage points is estimated to raise domestic food inflation by a minimum of 1.1 percentage points in the Slovak Republic, to a maximum of 6.0 percentage points in Ukraine, at the peak within 12-month. While in the case of the Slovak Republic the effect of the shock dissipates within 12-months, in all other cases the impact is more persistent. The peak response to world food price shocks is only slightly lower for inflation targeters than for countries with a pegged exchange rate system, suggesting that in the formers exchange rate movements do not damp much of the shock. 
Table 2. Response of Domestic Food Inflation to International Food Price Inflation Shocks (Percentage points) $1 / 2 /$

\begin{tabular}{lccc}
\hline & $\begin{array}{c}\text { Response after } \\
\text { 6 months }\end{array}$ & $\begin{array}{c}\text { Response after } \\
\text { 12 months }\end{array}$ & $\begin{array}{l}\text { Peak response } \\
\text { within } 12 \\
\text { months }\end{array}$ \\
\hline Estonia & 2.5 & 3.5 & 3.6 \\
Hungary & 2.0 & 2.6 & 2.6 \\
Latvia & 1.0 & 2.2 & 2.2 \\
Lithuania & 1.9 & 3.6 & 3.6 \\
Poland & 1.5 & 2.5 & 2.5 \\
Slovak Rep. & 1.0 & 0.0 & 1.1 \\
Turkey & 3.4 & 3.9 & 4.0 \\
Ukraine & - & 6.0 & 6.0 \\
Average & 1.9 & 3.0 & 3.2 \\
Inflation targeters & 2.3 & 3.0 & 3.0 \\
Pegged exchange rates & 1.6 & 3.1 & 3.3 \\
\hline
\end{tabular}

Source: IMF, International Financial Statistics, national authorities, and author's estimates. $1 /$ Results are reported only for countries for which responses are significant at 95 percent (or higher) level.

2/ Size of the shock: 10 percentage point increase in international food price inflation.

Domestic factors also have a significant effect on domestic food and fuel price inflation. Indeed, variance decompositions suggest that, historically, 30 percent of the variability of domestic fuel prices can be attributed to global price shocks, and only 10 percent of the volatility in domestic food prices can be attributed to changes in international food prices. Domestic factors - such as local weather conditions, rising wages and transportation costs, increasing local demand for higher-value-added food items driven by income convergence, and continuing trade integration - are likely to have an important influence on local food prices. $^{7}$

It is also useful to examine the impact of domestic food and fuel prices on core inflation, to assess whether European emerging economies are susceptible to second round effects, which could be long lasting. Indeed, the analysis of the VAR impulse response suggests that core inflation responds significantly to shocks to domestic energy and food inflation in several countries (Table 3). Also, the impact of these shocks appears to persist past beyond 12months in all countries - with the exception of Turkey.

\footnotetext{
${ }^{7}$ For net food exporters, surging international food prices also add to inflation pressures by boosting domestic demand.
} 
Table 3. Response of Core Inflation to Shocks to Domestic Food and Energy Price Inflation (Percentage points) 1/2/

\begin{tabular}{lccc}
\hline \multicolumn{1}{c}{$\begin{array}{c}\text { Response after } 6 \\
\text { months }\end{array}$} & $\begin{array}{c}\text { Response after } \\
\text { 12 months }\end{array}$ & $\begin{array}{c}\text { Peak response } \\
\text { within 12 months }\end{array}$ \\
\hline Response of Core Inflation to Shocks to Domestic Food Price Inflation & \\
Bulgaria & 0.3 & 0.2 & 0.6 \\
Czech rep. & 1.4 & 0.9 & 1.4 \\
Estonia & 0.9 & 1.3 & 1.3 \\
Latvia & 1.2 & 1.2 & 1.2 \\
Lithuania & 1.3 & 2.4 & 2.4 \\
Macedonia & - & 1.2 & 1.2 \\
Romania & 2.6 & 3.0 & 3.0 \\
Slovenia & 1.2 & 2.5 & 2.5 \\
& & & \\
Average & 1.3 & 1.6 & 1.7 \\
& & & \\
Response of Core Inflation to Shocks to Domestic Energy Price Inflation & 1.2 \\
Lithuania & 1.1 & 1.1 & 0.5 \\
Macedonia & 0.5 & 0.4 & 0.7 \\
Serbia & 0.7 & 0.6 & 2.7 \\
Turkey & 2.3 & - & 1.0 \\
Ukraine & 1.0 & 1.0 & 1.2 \\
Average & 1.1 & 0.8 & \\
\hline
\end{tabular}

Sources: IMF, International Financial Statistics, national authorities, and author's estimates. $1 /$ Results are reported only for countries for which responses are significant at 95 percent (or higher) level.

2/ Size of the shock: 10 percentage points in domestic food and energy price inflation.

\section{Panel Estimation}

One limitation of the VAR approach is that it does not control for some factors, such as price and income convergence, changes in taxations, and price liberalization, that may also affect inflation in emerging Europe. Therefore, to complement the analysis, we estimate a panel model for 18 European emerging economies, with quarterly data, that includes several additional explanatory variables. ${ }^{8}$

The set of regressors comprises the following variables: lags of the dependent variables, the GDP gap, as a measure of economic activity; the price level relative to EU-15 countries ${ }^{9}$, to

\footnotetext{
${ }^{8}$ The model is estimated for the whole sample countries including 18 European emerging economies, and for the group of NMS only.

${ }^{9}$ Relative prices are calculated using comparative price levels, obtained as ratios between purchasing power parities (PPPs) and nominal exchange rates, as in Honohan and Lane (2003).
} 
account for price level convergence; annual percent change in per capita income, as a measure of income convergence, the share of administrative price in the CPI basket, to measure the extent of price liberalization; an index of competition; annual changes in the VAT and sales rate; annual percent changes in nominal effective exchange rate; the money market rate; annual international oil and food price inflation; the relative prices of nontradeables to tradeables, to account for Balassa-Samuelson effects ${ }^{10}$ and excess demand in the non-tradeable sector ${ }^{11}$; and a measure of trade openness (also interacted with the GDP gap) to account for the impact of globalization. ${ }^{12} 13$

The domestic food equation includes as regressor also the deviation of agriculture value added from trend, to account for supply factors, possibly related to weather conditions, that might have affected domestic prices, and a measure of food exports, to account for recent increase in trade integration in emerging Europe. ${ }^{14}$

One relevant question, given that world commodity prices have eased recently, is whether inflation responds symmetrically to international commodity price positive and negative shocks. Inflation could rise steeply when food and fuel price increase, but fall little in the wake of declining commodity prices, due to market rigidities preventing prices or wages adjustments. To address this issue, in some regressions international food and fuel prices are replaced by two separate variables, respectively, for positive and negative changes. Similarly, in some estimates, GDP gap is replaced by two separate variables, respectively, for positive and negative output gaps, to ascertain whether market rigidities produce asymmetry in the inflation response during downturns and upturns. ${ }^{15}$

The lagged dependent variable coefficient is modeled as a country specific parameter, given that inflation persistence is likely to differ across countries. ${ }^{16}$ Ignoring such heterogeneity and assuming a homogeneous parameter - as other studies $\mathrm{do}^{17}$ — would produce inconsistent

\footnotetext{
${ }^{10}$ According to the Balassa-Samuelson effect, in a catching up economy stronger productivity growth in the tradable goods pushes up wages in this sector. Under the assumption of perfect labor mobility across sectors, wages rise in the whole economy. As productivity growth in the non-tradable sector is slower, higher wages in this sector translate into higher prices of non-tradable goods, and result in an increase in the overall price level. Numerous studies have estimated the size of the Balassa-Samuelson effect in transition economies. A survey on the empirical literature of the Balassa Samuelson effect in Central Europe is provided by Duvravko and Klau (2004). See also Égert (2007, 2008).

${ }^{11}$ For a theoretical exposition of the role of excess demand for non-tradables in boosting inflation in emerging Europe, see Zhou (2007).

${ }^{12}$ Previous studies on the link between globalization and inflation includes IMF (2006) which covers mostly advanced economies, and Allard (2007), which focuses on the NMS.

${ }^{13}$ This is a basically an "augmented" Phillips curve model. For theoretical underpinnings to the Phillips curve framework, see Galí and Gertler (1999).

${ }^{14}$ For the full list of variables, and data sources, see appendix.

${ }^{15}$ For a similar approach on advanced economies, see Van Den Noord and André (2007).

${ }^{16}$ Formal parameter restriction tests confirm the validity of this assumption.

${ }^{17}$ See, for example, Égert (2007) and Beirne and Staehr's (2008).
} 
estimates (Pesaran and Smith, 1995). The basic model is estimated with Ordinary Least Squares (OLS). ${ }^{18}$

Table 4 shows the results for the preferred model specification. ${ }^{19}$ The panel analysis confirms that world commodity prices are significant determinants of headline inflation and its subcomponents. Headline inflation response to commodity price shocks seems to be asymmetric in emerging Europe. On average, in the long run, a 1 percentage point surge in oil price inflation leads to an increase in headline inflation by 0.02 percentage points, whereas a decline in oil price inflation by the same amount results in a drop in headline inflation by $0.04 .^{20}$ The smaller inflation response to upward oil shocks suggests that producers are willing to absorb part of the shock by accepting lower margins to remain competitive. On the other hand, a 1 percentage point hike in food price inflation generates a 0.06 percentage point increase in inflation, but falls in food price inflation do not appear to have a significant impact on headline inflation. In the group of the NMS alone headline inflation response to commodity price shocks is also asymmetric (Appendix II).

Panel estimates also confirm the VAR finding that domestic energy and food prices significantly affect core inflation, with the pass-through from food price shocks higher than that from energy price shocks. The same result holds for the group of the NMS alone. The equation for food inflation indicates that local supply factors - measured by the deviation of value added in agriculture from a trend - contribute, together with changes in international prices, to domestic food inflation. On the other hand, a measure of food exports, accounting for recent increase in trade integration is found not to have a significant impact on food prices. Income convergence, and the associated increasing demand for higher-value-added food items, seems to be a significant determinant of food inflation, as the coefficient on the change in per capita income is found to be positive and significant in the food equation.

\footnotetext{
${ }^{18}$ For robustness check, the model is also estimated with Instrumental Variables (IV), to account for the potential correlation between the lagged dependent variable and the error term. Lagged values of the explanatory variables are used as instruments. Results are reported in Appendix II.

${ }^{19}$ These preferred model specifications include only variables with significant coefficients. Additional regression results are presented in Appendix II.

${ }^{20}$ This long-term pass-through is calculated as the ratio between the coefficient on the independent variable and 1 minus the coefficient on the lagged dependent variable.
} 
Table 4. Panel Regression Results

\begin{tabular}{|c|c|c|c|c|c|c|}
\hline Dependent variable & Headline inflation & Headline inflation & Headline inflation & $\begin{array}{c}\text { Core } \\
\text { inflation }\end{array}$ & Food Inflation & $\begin{array}{c}\text { Energy Inflation } \\
4 /\end{array}$ \\
\hline Lagged dependent variable $3 /$ & $\begin{array}{c}\mathbf{0 . 4} \\
(4.1)\end{array}$ & $\begin{array}{c}\mathbf{0 . 4} \\
(4.1)\end{array}$ & $\begin{array}{c}\mathbf{0 . 4} \\
(4.0)\end{array}$ & $\begin{array}{c}\mathbf{0 . 4} \\
(4.2)\end{array}$ & $\begin{array}{c}\mathbf{0 . 2} \\
(1.8)\end{array}$ & $\begin{array}{c}0.1 \\
(0.6)\end{array}$ \\
\hline GDP gap (lagged) & $\begin{array}{c}\mathbf{0 . 0 1 0} \\
(3.7)\end{array}$ & $\begin{array}{c}\mathbf{0 . 0 0 9} \\
(3.7)\end{array}$ & - & $\begin{array}{c}\mathbf{0 . 0 0 3} \\
(3.1)\end{array}$ & - & $\begin{array}{l}\mathbf{0 . 0 2} \\
(4.8)\end{array}$ \\
\hline GDP gap positive (lagged) & - & - & $\begin{array}{l}\mathbf{0 . 0 2} \\
(6.3)\end{array}$ & - & - & - \\
\hline GDP gap negative (lagged) & - & - & $\begin{array}{c}-0.0004 \\
(0.08)\end{array}$ & - & - & - \\
\hline Price level relative to EU15 (lagged) & $\begin{array}{c}-\mathbf{- 0 . 0 0 1} \\
(3.1)\end{array}$ & $\begin{array}{c}\mathbf{- 0 . 0 0 1} \\
(3.0)\end{array}$ & $\begin{array}{c}-\mathbf{- 0 . 0 0 1} \\
(2.4)\end{array}$ & $\begin{array}{c}-\mathbf{- 0 . 0 0 1} \\
(3.0)\end{array}$ & $\begin{array}{c}\mathbf{- 0 . 0 0 1} \\
(3.4)\end{array}$ & - \\
\hline International oil price & $\begin{array}{l}\mathbf{0 . 0 1 0} \\
(2.0)\end{array}$ & - & - & - & $\begin{array}{l}0.003 \\
(0.15)\end{array}$ & $\begin{array}{l}\mathbf{0 . 1 6} \\
(5.2)\end{array}$ \\
\hline International food price & $\begin{array}{c}\mathbf{0 . 0 4 0} \\
(1.8)\end{array}$ & - & - & - & $\begin{array}{l}\mathbf{0 . 1 4} \\
(1.8)\end{array}$ & - \\
\hline International oil price plus & - & $\begin{array}{l}\mathbf{0 . 0 2} \\
(3.3)\end{array}$ & $\begin{array}{l}\mathbf{0 . 0 2} \\
(3.1)\end{array}$ & - & - & - \\
\hline International oil price minus & - & $\begin{array}{l}-\mathbf{0 . 0 4} \\
(2.5)\end{array}$ & $\begin{array}{l}-\mathbf{0 . 0 4} \\
(2.2)\end{array}$ & - & - & - \\
\hline International food price plus & - & $\begin{array}{l}\mathbf{0 . 0 6} \\
(1.8)\end{array}$ & $\begin{array}{l}\mathbf{0 . 0 7} \\
(1.9)\end{array}$ & - & - & - \\
\hline International food price minus & - & $\begin{array}{l}-0.01 \\
(0.3)\end{array}$ & $\begin{array}{l}-0.007 \\
(0.15)\end{array}$ & - & - & - \\
\hline Domestic energy price (lagged) & - & - & - & $\begin{array}{r}\mathbf{0 . 0 7 4} \\
(4.1)\end{array}$ & - & - \\
\hline Domestic food price (lagged) & - & - & - & $\begin{array}{r}\mathbf{0 . 1 8 9} \\
(8.1)\end{array}$ & - & - \\
\hline VAT changes & $\begin{array}{r}\mathbf{0 . 0 0 2} \\
(5.1)\end{array}$ & $\begin{array}{r}\mathbf{0 . 0 0 2} \\
(5.2)\end{array}$ & $\begin{array}{r}\mathbf{0 . 0 0 2} \\
(5.9)\end{array}$ & $\begin{array}{r}\mathbf{0 . 0 0 2} \\
(3.8)\end{array}$ & $\begin{array}{r}\mathbf{0 . 0 0 2} \\
(2.2)\end{array}$ & - \\
\hline NEER (lagged) & $\begin{array}{l}-\mathbf{- 0 . 2 0} \\
(12.6)\end{array}$ & $\begin{array}{l}-\mathbf{- 0 . 2 1} \\
(13.2)\end{array}$ & $\begin{array}{l}-\mathbf{- 0 . 2 1} \\
(14.0)\end{array}$ & $\begin{array}{l}-\mathbf{- 0 . 1 0} \\
(3.7)\end{array}$ & $\begin{array}{l}-\mathbf{- 0 . 3 4} \\
(9.7)\end{array}$ & $\begin{array}{r}-1.04 \\
(8.7)\end{array}$ \\
\hline Interest rate (lagged) & $\begin{array}{c}-\mathbf{- 0 . 0 0 0 5} \\
(1.72)\end{array}$ & $\begin{array}{c}-\mathbf{- 0 . 0 0 0 6} \\
(2.37)\end{array}$ & $\begin{array}{c}-\mathbf{- 0 . 0 0 0 5} \\
(2.79)\end{array}$ & $\begin{array}{c}\mathbf{- 0 . 0 0 1} \\
(2.1)\end{array}$ & $\begin{array}{c}-\mathbf{0 . 0 0 1} \\
(2.5)\end{array}$ & - \\
\hline GDP gap*Trade openess (lagged) & $\begin{array}{c}\mathbf{- 0 . 0 0 6} \\
(2.5)\end{array}$ & $\begin{array}{c}\mathbf{- 0 . 0 0 6} \\
(2.7)\end{array}$ & & - & - & \\
\hline GDP gap positive*Trade openess (lagged) & - & - & $\begin{array}{r}-\mathbf{0 . 0 1} \\
(5.5)\end{array}$ & - & - & - \\
\hline GDP gap negative*Trade openess (lagged) & - & - & $\begin{array}{l}0.002 \\
(0.5)\end{array}$ & - & - & - \\
\hline Value added in agriculture (lagged) & - & - & & - & $\begin{array}{c}\mathbf{- 0 . 0 0 1} \\
(2.8)\end{array}$ & - \\
\hline Per capita income change & - & - & & - & $\begin{array}{c}\mathbf{0 . 3} \\
(2.5)\end{array}$ & - \\
\hline Adj. $R^{2}$ & 0.7 & 0.7 & & 0.7 & 0.5 & 0.7 \\
\hline No. of countries & 18 & 18 & & 17 & 16 & 17 \\
\hline No. of observations & 599 & 599 & & 479 & 474 & 517 \\
\hline
\end{tabular}

Source: Author's estimates.

1/ Absolute value of t-statistics in parentheses. t-statistics are calculated using standard errors that are robust to residuals cross-country contemporaneous correlation. Coefficient in bold are signficant at at least 90 percent significance level.

2/ All regressions include a constant among the explanatory variables.

3/ The reported coefficient is the average of country specific coefficients. Standard errors used to compute the t-statistic are obtained as the square root of the average of country specific coefficient variances.

4/ The energy inflation equation includes a dummy for Ukraine to account for the spike in energy import prices from Russia in 2006Q1-2007Q2. 
Cyclical fluctuations have a significant impact on inflation, as the coefficient on the GDP gap variable is positive and significant. The negative and significant coefficient on the interaction variable between trade openness and the GDP gap suggests that the sensitivity of headline inflation to the output gap has been falling in the wake of higher trade integration, in line with the results of Allard (2007). ${ }^{21}$ The inflation response seems to be asymmetric during cyclical upturns and downturns, as the coefficient on positive output gaps is positive and significant, while that on negative output gap is not significant. ${ }^{22}$

The coefficient on the lagged dependent variable is significant and its estimated size is consistent with the results from other studies on NMS (Allard, 2007, Beirne and Staehr, 2008). Other controls variables, namely the nominal effective exchange rate ${ }^{23}$, the interest rate, and changes in VAT rates, have significant coefficients, with the expected sign. ${ }^{24}$

The coefficients on variables measuring price liberalization and competition (the change in the share of administrative price in the CPI basket and the EBRD index of competition policy) are instead non significant. The relative price of non-tradeables to tradeables, accounting for Balassa-Samuelson effects and/or excess demand in the non-tradeable sector is found not to have a significant impact on inflation in emerging Europe, consistent with Égert's $(2007,2008)$ and Beirne and Staehr's (2008) findings on the NMS, and in contrast with the results by Dubravko and Klau (2008), also on the NMS.

The coefficient on the price level relative to EU-15 countries ${ }^{25}$ has a negative, significant coefficient, indicating that inflation rates tend to be higher in countries with low price levels relative to EU-15 countries, confirming earlier results by Lein-Rupprecht, León-Ledesma and Nerlich (2007) on the NMS. The estimated coefficient on the relative price variable from Table 4 suggests that in a country whose price level is 50 percent relative to the EU-15 average $^{26}$, annual headline inflation is about 3.0 percentage points higher than in country at the EU-15 average price level. The extent to which price level convergence feeds into domestic inflation could depend, however, on the exchange rate system, as price convergence could lead to an appreciating nominal exchange rate, rather than higher domestic inflation, in the case of true floater countries. Therefore, the regressions were also re-estimated for the two sub-groups of hard peggers and inflation targeters, separately. The coefficient on the price level relative to EU-15 countries is found to be of similar size in the two sub-groups, suggesting that, de facto, the exchange rate regime does not have an important impact on the inflation response to price convergence in emerging Europe.

\footnotetext{
${ }^{21}$ According to equation (1) in Table 4, the rise of trade openness over the recent years reduced the inflationoutput elasticity on average by 25 percent, from 0.4 to 0.3 . In other words, if output rises above its long-term trend by 1 percentage point today, inflation would increase by 0.3 percentage points next year, on average, compared to 0.4 percentage point increase in 1999 .

22 The Wald test confirms that the coefficients are statistically different at conventional significance level.

${ }^{23}$ The estimated coefficients to the nominal effective exchange imply that a one percent appreciation reduces headline inflation by about 0.2 percentage points in the following year. This low exchange rate pass-through estimate is consistent with a recent study by Beirne and Staehr (2008) on the NMS.

${ }^{24}$ Changes in sale tax rates, instead, do not have significant effects on inflation and its components.

${ }^{25}$ Panel unit root test confirm that this variable is stationary at conventional confidence level.

${ }^{26}$ On average, in emerging Europe the price level relative to EU-15 countries is 53 percent.
} 


\section{CONCLUSION: What is AHEAD FOR INFLATION IN EMERGING EUROPE?}

This paper has studied the role of international commodity price shocks, cyclical fluctuations, and catching up and transition related factors - such as price liberalization and price convergence - in driving inflation in 18 European emerging economies. It finds that international food and oil price shocks have a significant impact on domestic inflation, and explain on average about 19 percent of the variation in headline inflation. Cyclical fluctuations, while contributing to inflation, explain a relative small share of inflation variability. Inflation inertia, changes in consumption tax rates, nominal effective exchange rates movements, interest rates and price convergence are also significant determinants of inflation.

The empirical analysis suggests that inflation will fall in emerging Europe in the wake of the ongoing sharp reduction in world fuel prices, given that drops in international fuel prices affect inflation significantly and rapidly. On the other hand, the recent slowdown in international food prices may not have such a quick effect, as the inflationary impact of world food price shocks is rather persistent, and the response to falls in international food prices is not very strong. ${ }^{27}$ In the medium term, inflationary pressure from international commodity prices may resurface, as oil and food prices are expected to increase again in the next few years.

Possible second-round effects from the recent surge in domestic food and energy inflation remain a potential source of concern in the short-term, even as commodity prices moderate, as the empirical analysis suggests that spillovers from shocks to domestic food and energy inflation tend to be persistent in emerging Europe. The ongoing economic slowdown will certainly moderate inflationary pressure, nevertheless the econometric analysis seems to indicate that headline inflation response to downturns is not very large.

Convergence related factors are likely to remain a source of price pressures in the medium term. While price liberalization and relative price movements in the tradable and non tradable sector do not appear to be a contributing factor to inflation in emerging Europe, price convergence is estimated to add nearly 3 percentage points to headline inflation, for the average country whose price level is about 50 percent relative to the EU-15 average.

\footnotetext{
${ }^{27}$ In addition, international food prices are not expected to decline as sharply as fuel prices, as they are likely to be less affected by the global slowdown.
} 


\section{Appendix I: Variable Definition and Data Sources}

\section{VAR}

World food price inflation: log difference in the Commodity Food Price Index, which includes Cereal, Vegetable Oils, Meat, Seafood, Sugar, Bananas, and Oranges Price Indices. Source: IMF.

World fuel price inflation: $\log$ difference in the Crude Oil (petroleum), Price index, which is the simple average of three spot prices; Dated Brent, West Texas Intermediate, and the Dubai Fateh. Source: IMF.

Growth: log difference in the Industrial production index. Source: IMF, Haver, national authorities.

3-month money market rate: IMF, Haver, national authorities.

Nominal effective exchange rate: log difference in the nominal effective exchange rate. Source: IMF.

Headadline inflation: log difference in the Consumer Price Index. Source: Eurostat, national authorities.

Core inflation: for NMS and Turkey log difference in the HICP Overall index excluding energy, food, alcohol and tobacco. Source: Eurostat. For the other countries a measure of core inflation - as much as possible consistent with the HICP Overall index excluding energy, food, alcohol and tobacco definition - was constructed using national authorities data.

Domestic energy inflation: for NMS and Turkey log difference in the HICP Energy component. Source: Eurostat. For the other countries a measure of domestic energy inflation - as much as possible consistent with the HICP energy component definition - was constructed using national authorities data.

Domestic food inflation: for NMS and Turkey log difference in the HICP food component. Source: Eurostat. For the other countries a measure of domestic food inflation-as much as possible consistent with the HICP food component definition - was constructed using national authorities data.

\section{Panel}

GDP gap: actual real GDP minus trend GDP (obtained through the HP filter) in percent of trend GDP.

Price level relative to EU-15 countries: Relative prices are calculated using comparative price levels, obtained as ratios between purchasing power parities (PPPs) and nominal exchange rates. Source: IMF. 
Per capita income: log difference in per capita income. Source: IMF.

Administrative prices: share of administrative price in the CPI basket (in per cent) or number of goods with administered prices in EBRD-15 basket. Source: EBRD

Index of competition. Source : EBRD.

VAT and sales rates. Source: EU Commission, national authorities.

Relative prices of non-tradeables to tradeables. Source: Eurostat, National authorities.

Trade openness: Exports plus imports (percent of GDP). Source: IMF.

Deviation of agriculture value added from trend: actual agriculture real value added minus trend value added, obtained through the HP filter (percent of trend value added). Source: Haver, Dx. 


\section{Appendix II: Other Panel Results}

Additional Explanatory Variables and Instrumental Variables Estimates

\begin{tabular}{|c|c|c|c|c|c|}
\hline Estimation method & OLS & OLS & OLS & IV & IV \\
\hline Dependent variable & Headline inflation & $\begin{array}{l}\text { Headline } \\
\text { inflation }\end{array}$ & Headline inflation & Headline inflation & Core inflation \\
\hline \multirow[t]{2}{*}{ Lagged dependent variable 3 / } & 0.4 & 0.4 & 0.4 & 0.4 & 0.5 \\
\hline & $(3.6)$ & $(4.8)$ & $(3.9)$ & $(3.9)$ & $(4.3)$ \\
\hline \multirow[t]{2}{*}{ GDP gap (lagged) } & 0.008 & 0.010 & 0.009 & 0.011 & 0.002 \\
\hline & $(3.0)$ & $(3.2)$ & $(3.7)$ & $(4.6)$ & $(2.0)$ \\
\hline GDP gap positive (lagged) & - & - & - & - & - \\
\hline GDP gap negative (lagged) & - & - & - & - & - \\
\hline \multirow[t]{2}{*}{ Price level relative to EU15 (lagged) } & -0.001 & -0.001 & -0.001 & -0.001 & -0.0004 \\
\hline & $(2.0)$ & $(4.8)$ & $(3.0)$ & $(2.4)$ & $(2.3)$ \\
\hline International oil price & - & - & - & - & \\
\hline International food price & - & - & - & - & - \\
\hline \multirow[t]{2}{*}{ International oil price plus } & 0.03 & 0.02 & 0.02 & 0.02 & - \\
\hline & $(3.7)$ & (2.9) & $(3.2)$ & (3.6) & \\
\hline \multirow[t]{2}{*}{ International oil price minus } & -0.03 & -0.04 & -0.04 & -0.06 & - \\
\hline & $(2.0)$ & $(2.3)$ & $(2.5)$ & $(2.3)$ & \\
\hline \multirow[t]{2}{*}{ International food price plus } & 0.06 & 0.02 & 0.06 & 0.06 & - \\
\hline & $(2.0)$ & $(1.8)$ & $(1.8)$ & $(1.7)$ & \\
\hline \multirow[t]{2}{*}{ International food price minus } & -0.009 & 0.006 & -0.01 & -0.05 & - \\
\hline & $(0.2)$ & $(0.2)$ & $(0.79)$ & $(1.0)$ & \\
\hline \multirow[t]{2}{*}{ Domestic energy price (lagged) } & - & - & - & - & 0.063 \\
\hline & & & & & $(3.2)$ \\
\hline \multirow[t]{2}{*}{ Domestic food price (lagged) } & - & - & - & - & 0.193 \\
\hline & & & & & $(8.6)$ \\
\hline \multirow[t]{2}{*}{ VAT changes } & 0.002 & 0.002 & 0.002 & 0.002 & 0.003 \\
\hline & $(6.3)$ & $(4.8)$ & $(5.2)$ & $(4.8)$ & $(4.8)$ \\
\hline \multirow[t]{2}{*}{ NEER (lagged) } & -0.21 & -0.20 & -0.21 & -0.19 & -0.06 \\
\hline & $(10.5)$ & $(13.0)$ & $(10.5)$ & $(12.0)$ & $(2.4)$ \\
\hline \multirow[t]{2}{*}{ Interest rate (lagged) } & -0.0009 & -0.0010 & -0.0006 & -0.001 & -0.0003 \\
\hline & $(2.5)$ & $(2.37)$ & $(2.4)$ & $(2.1)$ & $(0.9)$ \\
\hline \multirow[t]{2}{*}{ GDP gap*Trade openess (lagged) } & -0.005 & -0.006 & -0.006 & -0.007 & - \\
\hline & $(2.1)$ & $(2.2)$ & $(2.7)$ & $(3.9)$ & \\
\hline GDP gap positive*Trade openess (lagged) & - & - & - & - & - \\
\hline GDP gap negative*Trade openess (lagged) & - & - & - & - & - \\
\hline Value added in agriculture (lagged) & - & - & - & - & - \\
\hline Price Trad./ Price non trad. & $\begin{array}{l}0.04 \\
(1.2)\end{array}$ & - & - & & \\
\hline Competition & - & $\begin{array}{c}-0.004 \\
(0.5)\end{array}$ & - & - & - \\
\hline Trade openess & & & $\begin{array}{c}-0.0001 \\
(0.4)\end{array}$ & & \\
\hline Adj. $R^{2}$ & 0.7 & 0.7 & 0.7 & 0.7 & 0.7 \\
\hline No. of countries & 18 & 17 & 18 & 18 & 17 \\
\hline No. of observations & 531 & 562 & 599 & 551 & 449 \\
\hline
\end{tabular}

Source: Author's estimates.

1/ Absolute value of t-statistics in parentheses. t-statistics are calculated using standard errors that are robust to residuals cross-country contemporaneous correlation. Coefficient in bold are signficant at at least 90 percent significance level. 2/ All regressions include a constant among the explanatory variables.

3/ The reported coefficient is the average of country specific coefficients. Standard errors used to compute the t-statistic are obtained as the square root of the average of country specific coefficient variances.

4/ The energy inflation equation includes a dummy for Ukraine to account for the spike in energy import prices from Russia in 2006Q1-2007Q2. 
Panel Regression Results for NMS only

Dependent variable Headline inflation

Headline inflation

Core inflation

Food Inflation

Energy Inflation

Lagged dependent variable 3/

GDP Gap (lagged)

GDP gap positive (lagged)

GDP gap negative (lagged)

Price level relative to EU15 (lagged)

International oil price

International food price

International oil price plus

International oil price minus

International food price plus

International food price minus

Domestic energy price (lagged)

Domestic food price (lagged)

VAT change

NEER (lagged)

Interest rate (lagged)

GDP Gap*Trade openess (lagged)

Value added in agriculture (lagged)

Per capita income change

Adj. $\mathrm{R}^{2}$

No. of countries

No. of observations

\section{5}

(5.1)

0.01

(3.7)

$-$

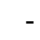

$-0.001$

(4.3)

0.01

(2.4)

0.06

(2.1)

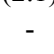

$-$
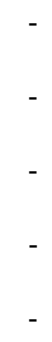

0.001

(1.6)

$\mathbf{- 0 . 1 5}$

(7.4)

$-0.0002$

$(0.4)$

$-0.006$

(2.6)

-

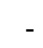

0.7

10

381
0.5

(5.5)

0.01

(3.4)

$-$

$-0.001$

(4.2)

-

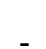

0.02

(4.7)

$\mathbf{- 0 . 0 4}$

(2.3)

0.08

(2.8)

0.03

(0.8)

-

$-$

0.001

(0.9)

$\mathbf{- 0 . 1 6}$

(7.9)

$-0.0003$

(0.7)

$\mathbf{- 0 . 0 0 6}$

(2.28)

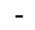

$-$

0.7

10
0.6

(9.0)

$\mathbf{0 . 0 0 2}$

(5.4)

-

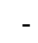

$\mathbf{- 0 . 0 0 1}$
$(2.9)$
-

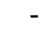

$-$

$-$

$-$

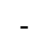

-

0.070

(7.3)

$\mathbf{0 . 2 0 0}$

(18.4)

0.000

$(0.25)$

$\mathbf{- 0 . 0 3}$

(2.3)

0.000

$(0.5)$

-

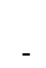

-

-

(2.7)

(3.4)

0.4

$\begin{array}{ll}0.8 & 0.4\end{array}$

$10 \quad 10$

$314 \quad 335$

0.18

(2.5)

$-0.002$

(0.7)

(6.6)

0.000

(0.4)
0.1

(1.3)

0.006

(1.9)

0.16

(7.2)

0.3

10

Source: Author's estimates.

1/ Absolute value of t-statistics in parentheses. t-statistics are calculated using standard errors that are robust to residuals cross-country contemporaneous correlation. Coefficient in bold are signficant at at least 90 percent significance level.

$2 /$ All regressions include a constant among the explanatory variables.

3/ The reported coefficient is the average of country specific coefficients. Standard errors used to compute the t-statistic are obtained as the square root of the average of country specific coefficient variances. 


\section{REFERENCES}

Allard C., 2007, "Inflation in Poland: How Much Can Globalization Explain?," IMF Working Paper 07/41 (Washington: International Monetary Fund).

Basu R., G. Kamber, H. Takizawa, and H. Zebregs,2007, “Understanding Russia’s Inflation in the Post-1998 Crisis Period," IMF Country Report 07/352.

Beirne J. and K. Staehr, 2008, "Determinants of Inflation in the New EU Countries from Central and Eastern Europe: A Panel Data Approach," paper presented at the ECFIN Workshop on "What drives inflation in the new EU member states?," Brussels, October 22, 2008.

Blanchard, O.J., and J. Galí, 2007, "The Macroeconomic Effects of Oil Shocks: Why Are the 2000s So Different from the 1970s?," NBER Working Paper No. 13368 (Cambridge, Massachusetts: National Bureau of Economic Research).

Choueiri N., Ohnsorge F., and van Elkan R., 2008, "Inflation Differential in the EU: A Common (Factors) Approach with Implications for EU8 Euro Adoption Prospects," IMF Working Paper 08/21 (Washington: International Monetary Fund).

Égert B., 2007, "Real Convergence, Price Level Convergence and Inflation Differentials in Europe," Oesterreichische National Bank Working Paper No. 138.

,2008, "Catching Up and Transition Related Inflation", paper presented at the ECFIN Workshop on "What drives inflation in the new EU member states?," Brussels, October 22, 2008.

Dubravko M. and M. Klau, 2004, “The Balassa Samuelson Effect in Central Europe: A Disaggregated Analysis," Comparative Economic Studies, 46(1), pp. 63-94. , 2008, "Catching-up Inflation in Transition Economies: the Balassa-Samuleson Effect Revisited," paper presented at the ECFIN Workshop on "What drives inflation in the new EU member states?," Brussels, October 22, 2008.

Franta M., B. Saxa, and K. Smidkova, 2008, "Is Persistence a Driving Force of Inflation in the new EU Member States?," paper presented at the ECFIN Workshop on "What drives inflation in the new EU member states?," Brussels, October 22, 2008.

Galí, Jordi and Mark Gertler, 1999, "Inflation Dynamics: A Structural Econometric Analysis," Journal of Monetary Economics, Vol. 44, pp. 195-222.

Hammermann F. and M. Flanagan, 2007, "What Explains Persistent Inflation Differentials Across Transition Economies?," IMF Working Paper 07/189.

Honohan P., and P. Lane, 2003, “Divergent Inflation Rates in EMU,” Economic Policy, October, pp. 357-394. 
International Monetary Fund (IMF), 2006, World Economic Outlook, Chapter III: "How Has Globalization Affected Inflation?," World Economic and Financial Surveys, pp.97143 (Washington, April). , 2008a, Regional Economic Outlook: Western Hemisphere, Chapter III: "World Commodity Prices and LAC Inflation," pp. 39-46 (Washington, April). ,2008b, Regional Economic Outlook: Europe, Chapter II: “Copying with High Commodity Prices," pp. 19-36 (Washington, October).

, 2008c, World Economic Outlook, Chapter III: "Is Inflation Back? Commodity Prices and Inflation," World Economic and Financial Surveys, pp. 93-128 (Washington, October).

Lein-Rupprecht, S. M., M. A. León-Ledesma, and C. Nerlich, 2007, "How is Real Convergence Driving Nominal Convergence in the New Member States?," ECB Working Paper No. 827 (Frankfurt: European Central Bank).

Mody A. and F. Ohnsorge, 2007, "Can Domestic Policies Influence Inflation?," IMF Working Paper 07/257 (Washington: International Monetary Fund).

Pesaran H. and R. Smith, 1995, "Estimating Long-run Relationships from Dynamic Heterogeneous Panels," Journal of Econometrics 68, pp. 79-113.

Schnabl G., 2008, "Exchange Rate Regime and Inflation in the New EU Member States," paper presented at the ECFIN Workshop on "What drives inflation in the new EU member states?," Brussels, October 22, 2008.

Stavrev E. , 2008, "Driving Forces of Inflation in the New EU 10 Members," paper presented at the ECFIN Workshop on "What drives inflation in the new EU member states?," Brussels, October 22, 2008.

Surti J., 2008, “What Drives Inflation in Slovenia?," International Monetary Fund (mimeo).

Vanags and Suardi, 2008, "Inflation Forecasting in the New EU Member States - An Overlooked Role of Money?," paper presented at the ECFIN Workshop on "What drives inflation in the new EU member states?", Brussels, October 22, 2008.

Van den Noord, P. and C. André, 2007, "Why has Core Inflation Remained so Muted in the Face of the Oil Shock?," OECD Economics Department Working Papers, No. 551 (Paris: OECD).

Zhou J., 2007, “Inflation in Bulgaria: Convergence or EU-phoria?”, International Monetary Fund (mimeo). 